Зимаросва А. А., кандидат біологічних наук

Житомирський національний агроекологічний університет

\title{
ДОСЛІДЖЕННЯ ПРОСТОРОВИХ МОДЕЛЕЙ ВАРІЮВАННЯ УРОЖАЙНОСТІ КАРТОПЛІ У ПОЛІСЬКІЙ ТА ЛІСОСТЕПОВІЙ ЗОНАХ УКРАЇНИ
}

\author{
Рецензент - доктор сільськогосподарських наук В. М. Положенець
}

Мета статті - встановлення закономірності просторово-часової варіабельності урожайності картоплі у Поліський і Лісостеповій зонах України та визначення співвідношення факторів динаміки агроекономічної та агроеклогічної природи.

Методика дослідження. Закономірності просторової неоднорідності урожайності картоплі на території 267 адміністративних районів Украӥни протягом 27 років вивчалися за допомогою аналізу головних компонент (РСA). Статистичний аналіз виконаний за допомогою програмного продукту Statistica 10, а також бібліотеки REdaS для середовища статистичних розрахунків $R$.

Результати дослідження. Аналіз головних компонент залишків моделі часового тренду дозволив встановити три аспекти мінливості врожайності картоплі в межах дослідженої території, або головні компоненти. Разом иі три головні компоненти описують 43,1\% загальної варіабельності урожайності картоплі. Змінні, які застосовані в аналізі головних компонент, є порядковими величинами - роками, тому навантаження головних компонент на них можуть бути представлені, як динамічні зміни у часі. Тому головні компоненти віддзеркалюють спечифічні патерни коливальної природи варіювання врожайності картоплі у часі, які є просторово визначеними. На основі характеру варіювання нами зроблені припущення стосовно природи даних головних компонент.

Елементи наукової новизни. Вперше було застосовано аналіз головних компонент щцодо врожайності картоплі в Украӥні та виявлено фактори, що обумовлюють ї̈ мінливість.

Практична значущість. Карти просторового варіювання головних компонент можуть бути основою для агроекологічного зонування території.

Ключові слова: урожайність, картопля, варіювання, динаміка, тренд, аналіз головних компонент.

Зимаросва Анастасія Анатоліївна - кандидат біологічних наук, доцент кафедри експлуатації лісових ресурсів, Житомирський національний агроекологічний університет, Старий Бульвар, 7, м. Житомир, 10008, Україна, e-mail: nastya.zymaroeva@gmail.com, ORCID ID: 0000-0001-9382-8269.

Постановка проблеми. Картопля $є$ однією із найбільш цінних і стратегічно важливих (після зернових) видів сільськогосподарських культур в Україні, яка забезпечує продовольчу безпеку держави. На врожайність картоплі впливає чимало факторів, зокрема й кількість опадів (грунтова вологість) і температура, строки посадки, якість посадкового матеріалу, системи удобрення і захисту тощо. Окрім екологічних на врожайність цієї культури впливають агроекономічні фактори, які визначають особливості технологічного процесу вирощування. Проте наразі невідомо, які 3 цих факторів $\epsilon$ визначальними у варіюванні врожайності картоплі в Україні.

Аналіз останніх досліджень і публікацій, у яких започатковано розв'язання даної проблеми. Коливання урожайності культур у просторі та часі $\epsilon$ реальністю сільськогосподарського виробництва. Щорічне варіювання врожайності може бути спричинене відмінностями в таких факторах, як сезонні погодні умови, тиск бур'янів, шкідників і хвороб та доцільністю управлінських рішень, щодо технології вирощування культур [3].
Оскільки урожайності культури часто неоднорідні у просторі та в часі, то варіювання врожайності можна розбити на ії просторові та часові компоненти. Синхронність та постійність $€$ важливими компонентами просторово-часової мінливості. Коли урожайність культури одночасно (в один і той самий рік) зростає або знижується в кожному 3 двох регіонів країни, вони $є$ синхронними. Постійність, з іншого боку, означає стійкі відмінності в рівні врожайності між двома регіонами або іншими просторовими одиницями. Просторові моделі $\epsilon$ діагностичними, коли вони використовуються для виявлення прихованих механізмів у ландшафті, а також прогностичними, коли вони вказують на можливий майбутній розвиток процесу [6].

Існує кілька підходів до вивчення довготермінових трендів врожайності сільськогосподарських культур на основі процесів або статистичних моделей [11]. У цьому дослідженні ми використовуємо аналіз головних компонент (Principle component analysis - PCA) - статистичний метод, що широко використовується при дослідженні та аналізі даних [12]. Цей непараметричний метод 


\section{СІЛЬСЬКЕ ГОСПОДАРСТВО. РОСЛИННИЦТВО}

стискає розмір набору даних і тим самим допомагає виявити деякі спрощені структури, які приховані в наборі даних. Аналіз головних компонент був застосований різними дослідниками 3 метою вивчення та характеристики співвідношення регіональних змінних та пов'язаних 3 ними факторів навколишнього середовища та кількісної оцінки просторової мінливості цих змінних $[8,10]$. У екологічних дослідженнях звичайним застосуванням PCA є набори даних про навколишнє середовище, наприклад, дані біогеохімії грунтів [8], дані про поширеність певних біологічних видів тощо [9]. Цей метод, застосований щодо показників врожайності, дозволяє виявити фактори (головні компоненти), які вносять найбільший внесок у варіювання урожайності культури та визначити їх природу.

Мета статті - встановити закономірності просторово-часової варіабельності урожайності картоплі у Поліський і Лісостеповій зонах України та визначити співвідношення факторів динаміки агроекономічної й агроеклогічної природи.

Завдання дослідження - у результаті проведення аналізу головних компонент, виявити фактори, що найбільше впливають на врожайність картоплі та встановити їх природу.

Матеріал та методи дослідження. Дані по урожайності картоплі у Поліський та Лісостеповій зонах України представлені Державною службою статистики України. Відомості охоплюють часовий період з 1991 по 2017 рр. Дані мають характер середньої врожайності культури по адміністративному району. Територія охоплює 206 адміністративних районів 3 десяти областей України (Вінницька, Волинська, Житомирська, Київська, Львівська, Рівненська, Тернопільська, Хмельницька, Черкаська, Чернігівська).

Статистичний аналіз виконаний за допомогою програмного продукту Statistica 10. Індекс Кайзера-Мейера-Олкіна (KMO) був застосований для усього об'єму даних щодо визначення адекватності зібраних матеріалів для проведення аналізу головних компонент. Оскільки КМО дорівнює 0,58 то, відповідно до емпіричного правила Кайзера [7], досліджені дані слід визнати придатними для проведення аналізу головних компонент помірно. Обчислення виконані за допомогою бібліотеки REdaS для середовища статистичних розрахунків R [13]. Для обчислення глобального коефіцієнта просторової автокореляції застосована статистика IМорана, яка подібна до коефіцієнта кореляції Пірсона. Обидві статистики варіюють у межах від +
1,0 (указує на сильну позитивну кореляцію) до 0 (указує на випадковий патерн) та до -1,0 (указує на сильну негативну автокореляцію). Глобальна статистика Морана обчислена зі застосуванням програми Geoda095i.

Результати досліджень. У наших попередніх дослідженнях встановлено, що динаміка врожайності картоплі в дослідженому регіоні найбільш вдало може бути описана за допомогою поліному четвертого порядку. Регресія за допомогою поліному четвертого порядку пояснює значну частину дисперсії урожайності картоплі (від 65 до $88 \%$ залежно від району досліджень) [2]. Наявність тренду, математична форма якого $є$ незмінною, вказує на наявність постійно діючих зовнішніх факторів на динаміку процесу. Як такий фактор ми розглядаємо агроекономічні умови господарювання. Але на кінцевий результат вплив здійснюють і фактори іншої природи, що мають локальний характер. У подальшому аналізі будуть застосовані залишки регресійної моделі. Ці залишки також мають складну природу. Безумовно, це може бути випадковий шум, пов'язаний 3 об' єктивними помилками у вихідних даних. Також у регресійних залишках ми можемо очікувати компоненту, яка пов' язана з регулярним варіюванням i яка найбільш ймовірно має екологічну природу.

Регресійні залишки для адміністративних районів характеризуються різним рівнем варіювання, що може призвести до зміщених результатів аналізу головних компонент, оскільки змінні 3 найбільшою дисперсією мають тенденцію бути поясненими першими головними компонентами. Відповідно, усі виділені змінні повинні бути стандартизовані шляхом відняття середнього значення від відповідної змінної та поділу результатів на їх стандартне відхилення. Така стандартизація даних робить кожну трансформовану змінну такою, яка має рівну важливість у наступному аналізі.

Аналіз головних компонент залишків регресійної моделі дозволив встановити, що за процедурою Горна (Horn, 1965) кількість статистично вірогідних головних компонент становить 8 (табл. 1). Разом перші вісім головних компонент пояснюють 81,7 \% загальної варіабельності простору ознак. Для подальшого аналізу за критерієм «осипу» [4] ми залишили перші 3 головні компоненти, які разом пояснюють 43,1\% загальної варіабельності простору ознак. 
СІЛЬСЬКЕ ГОСПОДАРСТВО. РОСЛИННИЦТВО

1. Результати глобального аналізу головних компонент

\begin{tabular}{|c|c|c|c|c|c|}
\hline $\begin{array}{c}\text { Головна ком- } \\
\text { понента }\end{array}$ & $\begin{array}{c}\text { Налаштоване* вла- } \\
\text { сне значення }\end{array}$ & Власне значення & Зсув & $\begin{array}{c}\text { Пояснена } \\
\text { варіація }\end{array}$ & $\begin{array}{c}\text { Стандартне від- } \\
\text { хилення }\end{array}$ \\
\hline 1 & 3,44 & 4,17 & 0,73 & 20,63 & 2,35 \\
\hline 2 & 1,73 & 2,35 & 0,62 & 12,17 & 1,81 \\
\hline 3 & 1,44 & 1,98 & 0,54 & 10,26 & 1,66 \\
\hline 4 & 1,46 & 1,92 & 0,46 & 9,55 & 1,60 \\
\hline 5 & 1,23 & 1,63 & 0,40 & 8,52 & 1,51 \\
\hline 6 & 1,13 & 1,47 & 0,34 & 7,24 & 1,39 \\
\hline 7 & 1,06 & 1,34 & 0,28 & 6,91 & 1,36 \\
\hline 8 & 1,00 & 1,23 & 0,23 & 6,44 & 1,32 \\
\hline
\end{tabular}

Примітка: * - за процедурою Горна.

Джерело: власні дослідження.

Змінні, які застосовані в аналізі головних компонент, $є$ порядковими величинами - роками, тому навантаження головних компонент на змінні можуть бути представлені як динамічні зміни в часі (рис. 1). Така форма представлення дозволяє змістовно інтерпретувати встановлені головні компоненти як коливальні процеси різної періодичності.

Головна компонента 1 описує 20,63 \% загальної варіабельності врожайності картоплі. Для неї властива від'ємна часова автокореляція з лагом 7 років та позитивна автокореляція з лагом 4 роки; переважає коливальний процес з періодом 6. Варіювання головної компоненти 1 має чітку просторову детер-

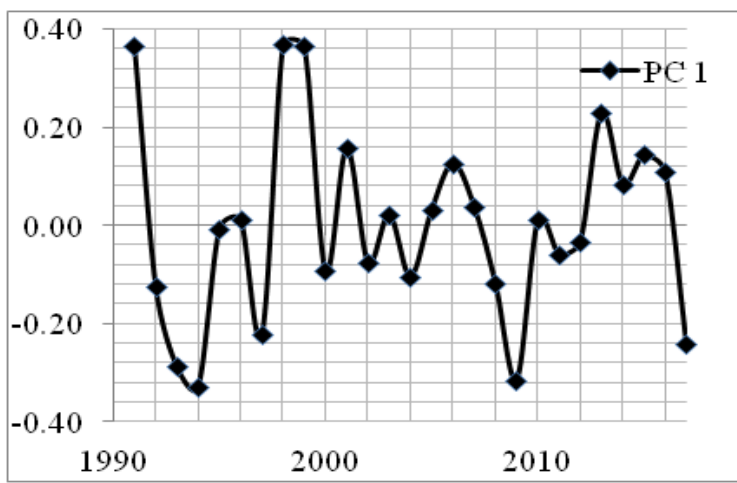

мінованість ( $I$-Морана $0,16, p=0,001)$. Зони 3 підвищеними значеннями головної компоненти 1 формують кластери в деяких районах сходу та півночі досліджуваного регіону (рис. 2). Зона зі зниженими значеннями цієї головної компоненти формують чіткий кластер у південно-східному напрямку від центру регіону. Слід відзначити, що сенс знаків головної компоненти - умовний, він вказує тільки на узгодженість динаміки урожайності в адміністративних районах. Відповідно, у районах 3 однойменним знаком урожайність змінюеться синхронно, тоді як протилежний знак вказує на протилежний напрямок динаміки.

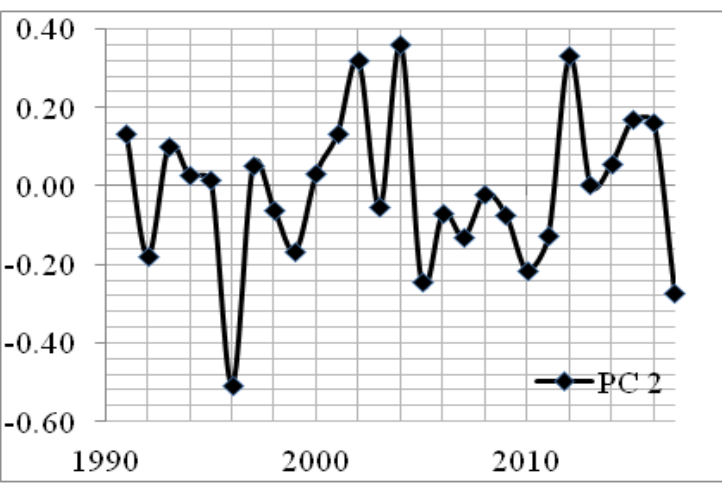

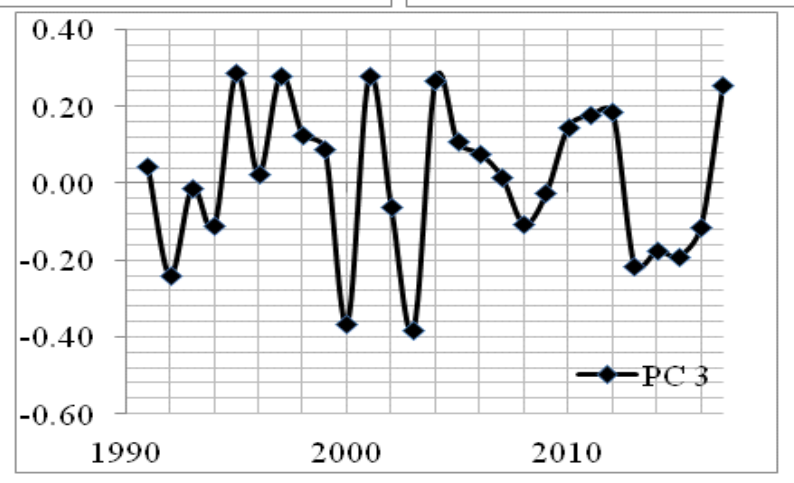

Рис. 1. Значення навантажень головних компонент 1-3 на змінні

Джерело: власні дослідження. 


\section{СІЛЬСЬКЕ ГОСПОДАРСТВО. РОСЛИННИЦТВО}

Головна компонента 2 пояснює 12,2 \% варіабельності простору ознак; для і1і коливання характерна від'ємна автокореляція 3 лагом 10 років та позитивна - 3 лагом 6 років. Переважаючий коливальний процес має період 4 роки. Ця компонента демонструє просторово закономірні патерни варіювання (I-Морана $-0,07, p=0,05)$. Від'ємне значення I-Морана вказує на просторовий патерн, який обумовлений тяжінням ділянок з більш високим значенням головної компоненти до ділянок 3 найменшим значенням та навпаки.

Головна компонента 3 пояснює 10,3 \% варіабельності урожайності картоплі; для неї властивий переважний коливальний процес 3 періодом 5 років. Висока просторова складова цієї головної компоненти підтверджується статистикою $I$-Морана $(0,28, p=0,001)$. Для цієї головної компоненти також характерна тенденція до затухання коливального процесу протягом періоду дослідження. Кластери 3 підвищеними значеннями головної компоненти 3 характерні для північного заходу та південного сходу, а з пониженими значеннями - для сходу та південного заходу досліджуваного регіону.

Аналіз головних компонент дозволяє визначити основні статистичні характеристики регіонального розвитку сільського господарства та виявити внутрішньо ускладнені взаємодії між вибраними змінами [10]. Глобальний аналіз головних компонент у проведених нами дослі- дженнях виявив наявність динамічних процесів урожайності картоплі коливальної природи 3 різною частотою. Схожа амплітуда коливань свідчить про те, що природа процесів є подібною або взаємообумовленою.

Умови зростання сільськогосподарських культур змінюються з часом внаслідок змін у природному середовищі та у технологіях вирощування [5, 11]. У цій статті ми простежуємо вплив саме екологічних факторів на зміну врожайності картоплі. Вважається, що серед екологічних чинників найбільший вплив на врожайність культур мають кліматичні фактори, такі як середньорічна кількість опадів, кількість сонячної радіації та температура вегетаційного періоду [11]. Також глобальне потепління негативно впливає на урожайність культур у глобальному масштабі [5]. Можна припустити, що головна компонента 1 (PCA 1), яка описує найбільшу частку варіації простору ознак $(20,63 \%)$ і характеризується коливальним процесом протягом найдовшого періоду (6 років), обумовлена саме кліматичними змінними. Для всіх інших головних компонент процеси коливань більш часті (4-5 років). Компоненти 3 високою частотою коливань можуть мати характер шуму або можуть мати екологічне походження внаслідок таких явищ, як вплив хвороб та шкідників або вплив погодних аномалій, які, зі свого боку, обумовлюються впливом кліматичних факторів.
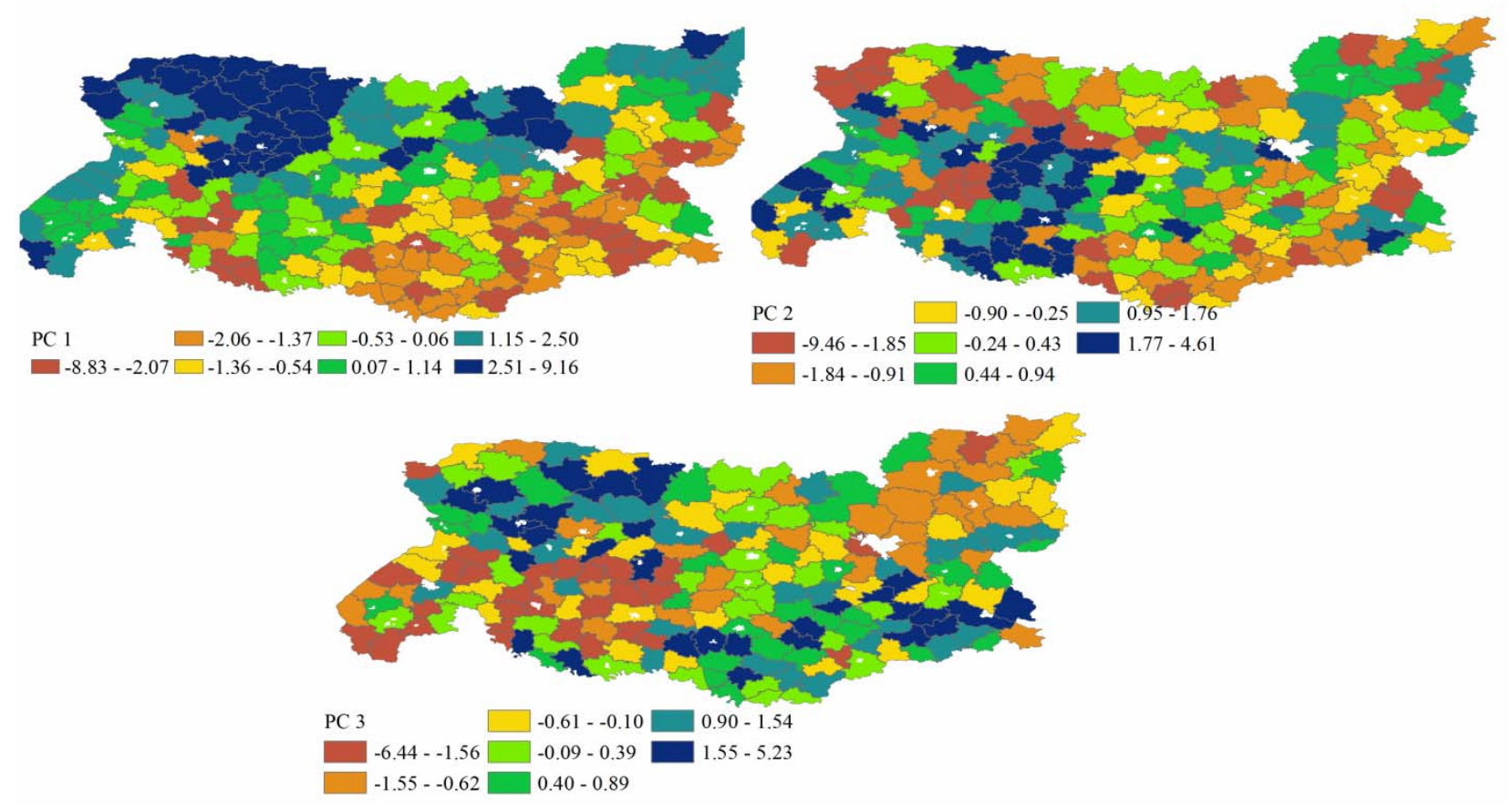

Рис. 2. Просторове варіювання головних компонент 1-3

Джерело: власні дослідження. 
Висновки та перспективи подальших досліджень. Аналіз головних компонент залишків моделі часового тренду дозволив установити три аспекти мінливості врожайності картоплі в межах дослідженої території, або головні компоненти. Разом ці три головні компоненти описують 43,1 \% загальної варіабельності простору ознак. Усі ці компоненти є просторово детерміновані. У динамічному аспекті ці головні компоненти характеризуються різними частотними характеристиками варіювання в часі. Головна компонента 1 (РСА 1), яка описує найбільшу частку варіації простору ознак $(20,63 \%)$ і характеризується

\section{БІБЛІОГРАФІЯ}

1. Агроекологічні основи вирощування картоплі [Текст] : навч. посіб. для студ. вищих навч. аграр. закл. / Авт. кол. : В. М. Положенець, М. С. Чернілевський, Л. В. Немерицька [та ін] ; за ред. В. М. Положенця ; М-во аграр. політики України, Держ. агроекол. ун-т. Київ : Світ, 2008. 196 c.

2. Зимароєва A. А. Особливості просторовочасового тренду врожайності зернових і зернобобових культур в Поліський та Лісостеповій зонах України. Вісник Полтавської державної аграрної академії. 2018. № 3. С. 66-73.

3 . Assessing the temporal stability of spatial patterns in crop yields using combine yield monitor data / [J. Lauzon, D. Fallow, O. O'Halloran et al.]. Canadian journal of soil science. 2005. Vol. 85(3). P. 439-451. DOI: https://doi.org/10.4141/S04-067.

4. Cattell R. B. The scree test for the number of factors. Multivariate Behavioral Research. 1966. Iss. 1. P. 245-76.

5. Chen $H$. The spatial patterns in long-term temporal trends of three major crops' yields in Japan. Plant Production Science. 2018. Vol. 21 (3). P. 177-185. DOI: https://doi.org/10.1080/1343943 X.2018.1459752.

6. Hammond M. P., Kolasa J. Spatial variation as a tool for inferring temporal variation and diagnosing types of mechanisms in ecosystems. PloS one.

\section{REFERENCES}

1. Polozhenets, V. M., Chernilevskyi, M. S., Nemerytska, L. V. et al. (2008). Ahroekolohichni osnovy vyroshchuvannia kartopli [Agro-ecological bases of potato cultivation]. Kyiv: Svit [In Ukrainian].

2. Zymaroieva, A. A. (2018). Osoblyvosti prostorovo-chasovoho trendu vrozhainosti zernovykh i zernobobovykh kultur v Poliskyi ta Lisostepovii zonakh Ukrainy. [Features of the spatiotemporal trend of grain and grain legumes yields in forest and коливальним процесом впродовж найдовшого періоду (6 років), на нашу думку, обумовлена кліматичними факторами. Схожа амплітуда коливань головних компонент свідчить про те, що природа процесів є подібною, або взаємообумовленою. Тому, з огляду на періодичність коливальних процесів, головні компоненти 2 і 3 можуть мати екологічне походження внаслідок таких явищ, як вплив хвороб та шкідників або вплив погодних аномалій. Подальше з'ясування природи головних компонент планується у наступних дослідженнях.

2014. Vol. 9(2). e89245. DOI: https://doi.org/ 10.1371/journal.pone.0089245.

7. Kaiser H. F. An Index of Factorial Simplicity. Psychometrika. 1974. Vol. 39(1). P. 31-36.

8. Kumar S., Lal R., Lloyd C. D. Assessing spatial variability in soil characteristics with geographically weighted principal components analysis. Computational Geosciences. 2012. Vol. 6 (3). P. 827835. DOI 10.1007/s10596-012-9290-6.

9. Legendre P., Gallagher E. Ecological Meaningful Transformations for Ordination of Species Data. Oecologia. 2001. Iss.129. P. 271-280.

10. Li Y. S., Huang M. B. Pasture yield and soil water depletion of continuous growing alfalfa in the Loess Plateau of China. Agr. Ecosyst. Environ. 2008. Vol. 124(1-2). P. 24-32. https://doi.org/10.1016/j.agee.2007.08.007.

11. Lobell D. B., Schlenker W., Costa-Roberts J. Climate trends and global crop production since 1980. Science. 2011. Iss. 333. P. 616-620.

12. Pearson K. On Lines and Planes of Closest Fit to Systems of Points in Space. Philosophical Magazine. 1901. Vol. 2(11). P. 559-572.

13. $\mathrm{R}$ Core Team. R: A language and environment for statistical computing (2017). R Foundation for Statistical Computing, Vienna, Austria. URL : https://www.R-project.org/.

forest-prairie zone of Ukraine]. Visnyk Poltavskoi derzhavnoi ahrarnoi akademii, 3, pp. 66-73. doi:10.31210/visnyk2018.03.10 [In Ukrainian].

3. Lauzon, J., Fallow, D., O'Halloran, O. et al. (2005). Assessing the temporal stability of spatial patterns in crop yields using combine yield monitor data. Canadian journal of soil science, 85(3), pp. 439-451. https://doi.org/10.4141/S04-067 [In English].

4. Cattell, R. B. (1966). The scree test for the 


\section{СІЛЬСЬКЕ ГОСПОДАРСТВО. РОСЛИННИЦТВО}

number of factors. Multivariate Behavioral Research, 1, pp. 245-276 [In English].

5. Chen, H. (2018). The spatial patterns in longterm temporal trends of three major crops' yields in Japan. Plant Production Science, 21 (3), pp. 177185. DOI: https://doi.org/10.1080/1343943X.2018.1 459752 [In English].

6. Hammond, M. P., Kolasa, J. (2014). Spatial variation as a tool for inferring temporal variation and diagnosing types of mechanisms in ecosystems. PloS one, 9(2), e89245. https://doi.org/10.1371/ journal.pone.0089245 [In English].

7. Kaiser, H. F. (1974). An Index of Factorial Simplicity. Psychometrika, 39(1), pp. 31-36 [In English].

8. Kumar, S., Lal, R., Lloyd, C. D. (2012). Assessing spatial variability in soil characteristics with geographically weighted principal components analysis. Computational Geosciences, 6 (3), pp. 827-835. DOI 10.1007/s10596-012-9290-6 [In English].

9. Legendre, P., Gallagher, E. (2001). Ecological
Meaningful Transformations for Ordination of Species Data. Oecologia, 129, pp. 271-280. [In English]

10. Li, Y. S., Huang, M. B. (2008). Pasture yield and soil water depletion of continuous growing alfalfa in the Loess Plateau of China. Agr. Ecosyst. Environ, 124(1-2), pp. 24-32. https://doi.org/10.1016/j.agee.2007.08.007

[In English].

11. Lobell, D. B., Schlenker, W. (2011). CostaRoberts, J. Climate trends and global crop production since 1980. Science, 333, pp. 616-620 [In English].

12. Pearson, K. (1901). On Lines and Planes of Closest Fit to Systems of Points in Space. Philosophical Magazine, 2(11), pp. 559-572 [In English].

13. R Core Team (2017). R: A language and environment for statistical computing. R Foundation for Statistical Computing, Vienna, Austria. URL : https://www.R-project.org/.

Зимароева А. А. Исследование пространственной модели варьирования урожайности картофеля в Полесской и Лесостепной зонах Украины

Целью данной работы было установление закономерности пространственно-временной вариабельности урожайности картофеля в Полесской и Лесостепной зонах Украины и определение соотношения факторов динамики агроэкономической и агроеклогичнои природы.

Методика исследования. Закономерности пространственной неоднородности урожайности картофеля на территории 267 административных районов Украины в течение 27 лет изучались с помощью анализа главньх компонент (PCA). Статистический анализ выполнен с помощью программного продукта Statistica 10, а также библиотеки REdaS для среды статистических расчетов R.

Результаты исследования. Анализ главных компонент остатков модели временного тренда позволил установить три аспекта изменчивости урожайности картофеля в пределах исследованной территории, или главные компоненты. Вместе эти три главных компоненты описывают 43,1\% общей вариабельности урожайности картофеля. Переменные, которые применены для анализа главных компонент, являются порядковыми величинами - годами, поэтому нагрузка главных компонент на них может быть представлена как динамические изменения во времени. Поэтому главные компоненты отражают специфические паттерны колебательной природы варьирования урожайности картофеля во времени, которые являются пространственно определенными. На основе характера варьирования нами сделаны предположения о природе этих главньх компонент.

Научная новизна работы заключалась в том, что впервые был применен анализ главных компонент относительно урожайности картофеля в Украине и выявлены факторы, обусловливающие ее изменчивость.

Практическая значимость. Карты пространственного варьирования главных компонент могут служить основанием для агроэкологического зонирования территории.

Ключевые слова: урожайность, картофель, варьирования, динамика, тренд, анализ главных компонент.

Зимароева Анастасия Анатольевна - кандидат биологических наук, доцент кафедры эксплуатации лесных ресурсов, Житомирский национальный агроэкологический университет, Старый Бульвар, 7, г. Житомир, 10008, Украина, e-mail: nastya.zymaroeva@gmail.com, ORCID ID: 0000-0001-93828269. 
Zymaroieva A. A. Investigating the spatial patterns of potato yields variation in Polissia and ForestSteppe zones of Ukraine

This paper is aimed at establishing the regularities of the spatial-temporal variability of potato yield in Polissia and Forest-Steppe zones of Ukraine and determining the correlation between the dynamics factors of agro-economic and agro-ecological nature.

Methods of research. The regularities of spatial heterogeneity of potato yield on the territory of 267 administrative districts of Ukraine for over 27 years were studied using the principal component analysis (PCA). The statistical analysis was conducted using the Statistica 10 software product, as well as REdaS library for the statistical calculations in R Programming Environment.

The research results. Principal components analysis of the time trend model residues enabled to establish three aspects of potato yield variability within the studied area, or the principal components. Taken together, these three principal components explain $43.1 \%$ of the overall potato yields variability. The variables used in the PCA are the ordinal quantities - the years, so the loadings of the principal components on the variables can be represented as dynamic changes in time. Therefore, the principal components of oscillatory patterns reflect the specific variation patterns of potato yield in time, and these patterns are spatially defined. These oscillatory processes are of ecological origin. Concerning the dynamic aspect, these principal components are determined by different frequency characteristics of variation in time. Based on the character of the variation, we made the assumptions about the nature of the given principal components.

Scientific novelty. It was for the first time that the PCA was used for studying the data concerning potato yields, and the factors that determined yields variability were identified.

Practical significance. Maps of the spatial variation of principal components can be the basis for agroecological zoning of the territory.

Key words: yield, potato, variation, dynamics, trend, the principle component analysis.

Zymaroieva Anastasiia Anatoliivna - Candidate (PhD) of Biological Sciences, Faculty of Forestry, Associate Professor at the Department of Forest Resources Utilization, Zhytomyr National Agro-Ecological University, 7, Staryi Bulvar, Zhytomyr, 10008, Ukraine, e-mail: nastya.zymaroeva@gmail.com, ORCID ID: 0000-0001- 9382-8269.

Стаття надійшла до редакції 01.03.2019 р.

Бібліографічний опис для цитування :

Зимароєва А. А. Дослідження просторових моделей варіювання урожайності картоплі у Поліській та Лісостеповій зонах України. Вісник ПДАА. 2019. № 1. С. 49-55.

DOI 10.31210/visnyk2019.01.06

Зимароєва Анастасія Анатолї̈вна, 2019 